\title{
A ÉtICA EM Lacan
}

\section{Ethics in Lacan}

LACAN, Jacques. Le Seminaire: livre XIX ... ou pire. (1971-1972) Paris: Editions du Seuil, 2011, 257 p. ISBN: 9782020971652. R\$ 75,56 .

LACAN, Jacques. Je parle aux murs. Paris: Editions du Seuil, 2011, 112 p. ISBN: 9782020971669 . R\$ 44,90.

A passagem do trigésimo ano do desaparecimento de Lacan (setembro de 1981) foi marcada pelo lançamento de duas obras bastante representativas da orientação ética e clínica de seu obstinado pensamento, o qual impõe uma leitura em conjunto: ... ou pire [... ou pior] e Je parle aux murs [Falo com as paredes]. É que à mesma época em que realizava no Panteão seu $19^{\circ}$ seminário, Lacan manteve uma série de conversações (entretiens) no hospital Sainte-Anne, nas quais buscou delimitar o lugar em que o analista há de estar para sustentar seu saber. Daí o título dessas conversações - O saber do psicanalista - que, uma vez divididas, parte foi intercalada a ... ou pire; parte deu origem a Je parle aux murs. A partir dessas conversações, Lacan chegou a um princípio ético: a psicanálise não poderia veicular senão "um saber que não pode fazer nada, o saber da impotência, logo, o analista há de atingir a ordem do gozo, sem visar à mestria e tampouco estar a serviço do poder, até porque "a verdade é o que se aproxima de um real".

Inconformado que era Lacan, o seu pensamento não se estagnava; marcado por uma incansável transgressão, ainda hoje não deixa de se impor e advertir: mesmo que às vezes necessário, o discurso do mestre é apenas um semblante, um artifício a serviço do que quer que seja. Portanto, extremo cuidado com quem o toma ao pé da letra. Às margens do atual império do gozo, não deixou de mostrar que restaurar o pai como mestre autoritário não resolve o sintomático declínio da autoridade paterna. De quem se crê todo-poderoso, ou acredite que a mulher só se satisfaça com o falo, aguarde o pior... a funesta ilusão de acreditar que uma relação sexual seja possível. Único na psicanálise a reinterpretar a pulsão de morte como tal, Lacan insistia em dizer que, para além da articulação entre quem fala e quem escuta, qualquer relação já traz esse gozo como efeito. Por isso e porque um sintoma tem um sentido, o de valor de verdade, a partir de 1970 buscou um discurso que atingisse a verdade de gozo e, enfim, a escrevesse. Ora, isso exige uma tradução, ou

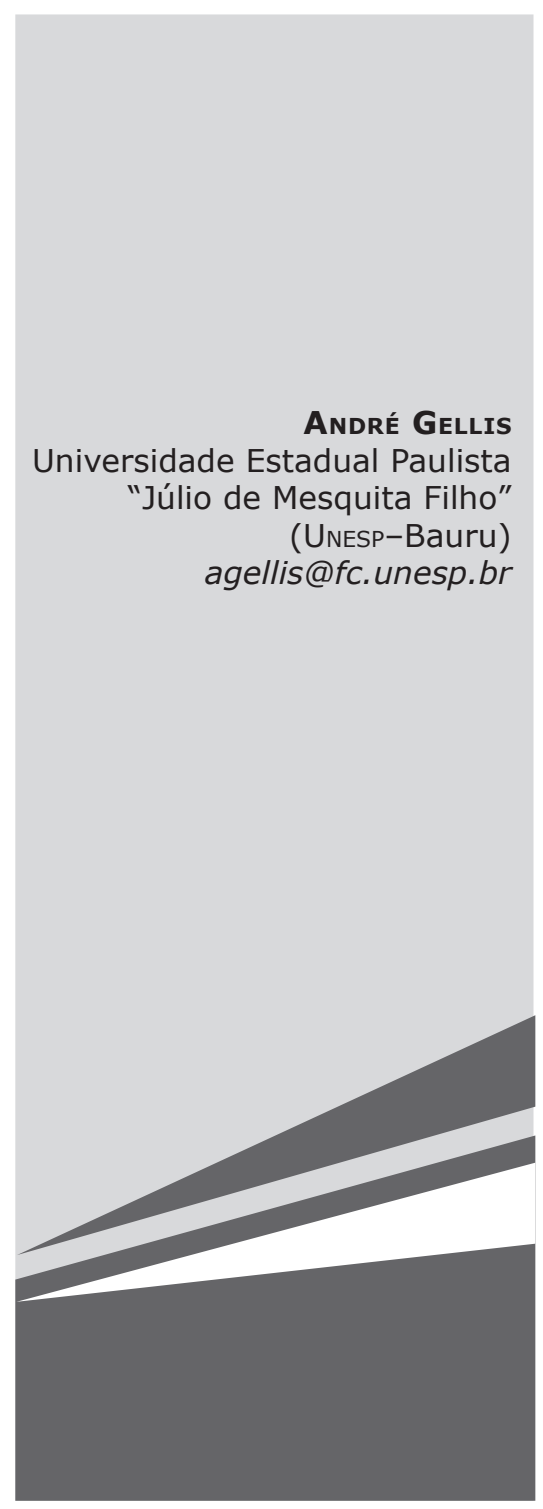


seja, uma interpretação que assinale o gozo que se obtém no que insiste e se repete em seu corpo e em seu dizer. Tal interpretação opera porque, inseparável das funções da fala, a verdade não é sintoma.

De fato, o legado de Lacan é, sobretudo, ético; releva do esforço de expor a todos o real de um gozo tal como ele os habita. Esforço porque nada se sabe de real sobre homens e mulheres, uma vez que inexiste significante para a diferença dos sexos. O que existe, o falo, não pode senão se ligar a um ou outro dos termos envolvidos, exclusivamente ao homem ou à mulher, nem estabelecer relação ou comunicação de um ao outro. Em uma frase: "Não há relação sexual”. Dessa evidência analítica, surgem algumas consequências éticas:

- não há relação sexual para os falantes justamente porque a fala se dá de modo tão preeminente que qualquer coisa da ordem do semblante acaba por especificar o ser falante, mesmo em termos de semblante de homem e de mulher;

- é somente da fala que provém o gozo, o gozo sexual;

- é o gozo que determina o ato sexual, a relação, mas apenas se o ser falante se deparar com a castração;

- por exigir a castração, o gozo sexual impede estabelecer um. Então, a questão recai sobre a dimensão do gozo, logo, da relação do ser falante com seu corpo - afinal, é para este e somente para ele que o gozo sexual emerge antes da reputada maturidade sexual.

"Não há relação sexual" foi o enunciado que mobilizou Lacan nos anos 70, época da liberação sexual que, não obstante, não assimilou que fazer do gozo a solução de todos os problemas é lançar-se em uma perpétua decepção. Apesar de toda excitação, essa liberação entregou apenas mais um discurso da mestria, não indo além da compulsão e da dependência. Era, pois, uma precaução ética o enunciado de Lacan, que reafirmava: "Você não goza... até porque... isso é muito perigoso".

A função ética decorre de um real. Em ... ou pire as reticências do título significam não somente que ele, Lacan, poderia sempre "fazer pior", mas, antes, o vazio necessário para que se possa dizer algo com a linguagem e chegar a um discurso que não seria semblante: ou um dizer que não seria semblante ... ou pior. Em Je parle aux murs, trata-se também de uma escolha ética: ou um dizer que se sustente na inexistência da relação sexual, ou... Nunca ignorar que "o significante é o gozo e que o falo não é senão seu significado"; jamais equivocar-se quanto às mulheres: embora não estejam na função fálica, não a negam; não há relação sexual, absolutamente.

De fato, não há relação que não seja simbólica. Se ela só passa a existir se for enunciada, escrita, falada, então qual articulação levaria a um discurso que concernisse ao real, e não fosse semblante?

"O real do qual falo é absolutamente inacessível, exceto por uma via matemática". Se o real que aí está existe antes que se o imagine ou o nomeie, a aposta de Lacan era a de buscar a sua formulação lógica. Nesse sentido, ... ou pire é a tentativa de escrever a razão lógica do que o inconsciente traz de gozo real. Daí a recorrência a Aristóteles, cuja lógica opera com o possível e o impossível, o contingente e o necessário, aos quais Lacan acres- 
centa a impotência. No limiar dos anos 1970, em que expressou mais de uma vez o seu temor disso "que se enraíza no corpo" e se chama racismo, em ... ou pire Lacan professou sua longa permanência no mundo, resgatou alíngua do mal-entendido e introduziu o matema, além de mencionar pela primeira vez os nós borromeanos que o ocupariam até o fim de sua vida. Para essa sua empreitada formalista, recorreu também a Pascal, Frege, Gödel, Cantor, Russell, Wittgenstein; e não fosse o fato de a psicanálise exigir uma lógica derivada de alíngua, ele não arriscaria transpor os efeitos da linguagem que se intercalam entre o real e o ser falante com a proposição de termos, tais como ao-menos-um, não-todo, não-toda, até chegar à primeira implicação lógica da ausência de relação sexual: Há d'um (Yad'lun).

Em contrapartida, se toda e qualquer relação é simbólica, e o real, por sua vez, se dá antes que o simbólico opere, então, no lugar do que escreveria a relação sexual como tal, surgem os impasses decorrentes da função do gozo sexual, gozo que jamais será absoluto porque fadado às inumeráveis formas de fracasso dadas ou pela castração, ou pela divisão. Não à toa, ... ou pire fala do gozo, apesar de o gozo sexual, por si só, não ser nada além de um produto local, orgânico, da competência do real, categoria que se opõe à linguagem, a qual estabelece com o gozo toda uma relação dialética. Se a linguagem aparece para preencher o vazio deixado pelo gozo - "a linguagem originariamente funciona em suplência do gozo sexual” -, este, por seu lado, se revela ser o alvo em direção ao qual a linguagem não cessa de se estender, pelo encadeamento dos significantes, todos condicionados pelo significante-mestre, o falo, sinônimo de gozo. Em poucas palavras, nada de gozo sem linguagem, absolutamente; nada de linguagem sem gozo.

É tão somente pela linguagem que se opera a sexuação no homem, isso porque "o sexo não define nenhuma relação no ser falante, em absoluto", dizia Lacan, que não se referia à "pequena diferença” anatômica prefigurada como valores sexuais homem e mulher, antecipados pelas palavras dos pais, as mesmas que distinguem alguém como menino ou menina. Porém, uma vez que a linguagem vai de par com o gozo, é de fato a relação que se estabelece com este último, o gozo, que fará de alguém homem ou mulher. Mas por que razão? A condição de ser falante introduz uma hiância (Spaltung) pela qual o inconsciente aparece. Por isso, no ato sexual, na cópula, está cada um por si, e não há relação: a ordem do sexo provém do semblante, semblantes de papéis sexuais dados de antemão, inclusive os das mulheres, infindáveis.

De fato, não se escapa da sexuação pela linguagem, nem as mulheres, as quais, como o homem, vivem sob a ascendência do significante-mestre, do ao-menos-um. Mas, "por razões evidentes", não são castradas e, portanto, não estão todas inteiras na dependência do falo - não-todas, ocultam "[... ] um outro gozo que o gozo fálico, o gozo feminino propriamente dito, que não depende de nenhuma forma". Se ao homem nada resta senão o insucesso do gozo pela castração, às mulheres, nada além do malogro do gozo por sua infindável divisão. Não-todas, as mulheres seriam para Lacan a discordância que refutaria Aristóteles por ter pensado o um e o ser juntos, o todo. Ora, fazer de dois, um é impossível. Daí não restar senão o amor, a suplência. Daí elas não falarem senão disso. 
Já para o homem, o gozo vem pela castração: a aceitação da lei do pai e a proibição do incesto autorizam desejar outras mulheres que não a mãe. "Todos castrados", regra absoluta com uma exceção: para a linguagem se dar e seguir ligando-se ao significante-mestre, é necessário que um lugar seja reservado a pelo menos uma figura da potência ilimitada - pai primevo, deus, mestre... Em todo caso, nada de gozo masculino sem esse ao-menos-um que teria escapado da castração.

De um lado, por conseguinte, o ao-menos-um, do outro, o não-todo. Como uma relação poderia se estabelecer entre duas estruturas existenciais tão distintas? No ato sexual, apesar da homologia dos corpos, entra-se menos em relação com o parceiro do que com o próprio gozo. Portanto, não há relação sexual que não imponha a tentativa de encontrar a lógica do gozo.

É a isso que Lacan se dedica em ... ou pire e Je parle aux murs, mas orientando-se por uma ética animada pelo não saber, ou melhor, pelo saber que não sabe de si. Ora, um saber não-sabido é um saber que se articula, que está estruturado. Antes de nada, o inconsciente é a própria subversão da estrutura do saber e de sua função. Esse novo estatuto do saber impõe um novo discurso: o do analista. Por isso Lacan retoma a teoria dos quatro discursos, dos quais três evadem-se do real pela via do semblante: o discurso do mestre; o discurso do universitário, arremedo de saber; e o discurso da histérica, a que se consagra a seduzir e reinar sobre um mestre. É na orla de tais evasões, na fronteira sensível entre a verdade e o saber, que o discurso do analista se situa. Este poderia ser o discurso que não fosse semblante e se consumasse em ato, se não restasse estabelecê-lo. Entre 1971-1972, Lacan buscou-o por meio da lógica e sempre na perspectiva de um discurso que libertasse o sujeito da escravização psíquica. Inevitável que o analista viesse à posição inapreensível do objeto de gozo e exigisse um discurso em que a fala alcançasse a função de ser "a única forma de ação que se coloca como verdade", algo de que nunca se teve ideia: deixar o sujeito se despojar de suas repetições para promover o desejo - eis a emancipação de um clínico obstinado por um discurso em que o dizer cavasse o lugar da verdade sem lhe renegar a sua estrutura de fala, que é também a da mentira. Se se pode dizer a verdade sem que a saiba, por que não o saber do psicanalista e sua ética?

DADOS DO AUTOR:

ANDRÉ GELLIS

Psicólogo e Psicanalista. Doutor em Psicologia pelo Instituto de Psicologia da USP. Professor do Departamento de Psicologia da UNESP - Bauru.

Recebido:08-02-2012

Aprovada: 20-03-2012 